\title{
BUDAYA CARI UNTUNG SEBAGAI PEMICU TERJADINYA FRAUD: SEBUAH STUDI ETNOGRAFI
}

\author{
Dewi Syahrina1 \\ Pendidikan Magister Akuntansi FEB \\ Universitas Brawijaya Malang \\ s.ri3n4@gmail.com
}

\author{
Gugus Irianto $^{2}$ \\ Jurusan Akuntansi FEB Universitas \\ Brawijaya Malang
}

\author{
Yeney Widya Prihatiningtyas ${ }^{3}$ \\ Jurusan Akuntansi FEB \\ Universitas Brawijaya Malang
}

\begin{abstract}
ABSTRAK
Penelitian ini bertujuan untuk mengetahui budaya yang memicu terjadinya fraud pada realisasi keuangan negara. Penelitian dilakukan pada instansi pemerintah daerah di Provinsi ABC. Metode etnografi ala Spradley dipilih untuk menemukan budaya pemicu tersebut. Hasil penelitian menunjukkan bahwa budaya yang memicu terjadinya fraud adalah budaya cari untung, yang terlihat dari kebiasaan "memanfaatkan" kebutuhan instansi, kebiasaan menyalahgunakan kewenangan yang dimiliki, dan kebiasaan menyiasati beberapa ketentuan keuangan negara pada PMK 113/PMK.05/2012 dan PMK 65/PMK.02/2015 untuk kepentingan pribadi maupun kelompok. Hasil penelitian ini memberikan informasi berupa bentuk-bentuk penyiasatan yang dilakukan, sehingga dapat dijadikan dasar sebagai bahan pertimbangan untuk perubahan atau perbaikan kebijakan dan peraturan yang disiasati tersebut.
\end{abstract}

Kata Kunci : Fraud; Instansi pemerintah; Etnografi; Budaya cari untung

\section{ABSTRACT}

This study aims to determine the culture that drives to fraud in the state finance realization. The study was conducted in a local government agency, ABC province. Spradley ethnographic method has choosen to find the trigger culture. The result shows that the culture that leads fraud is profit oriented culture, as seen from the a habit to find an oppotunities from the institution needs, a habit to abuse power, and a deceived habit of financial regulation, in PMK 113/PMK.05/2012 and PMK $65 / P M K .02 / 2015$, which done for personal or group interests. The result of this study provides forms of the deception, so it can be used as a consideration of changes or improvements the regulation.

Keywords: Fraud; Government agenc; Ethnographic; Profit oriented culture

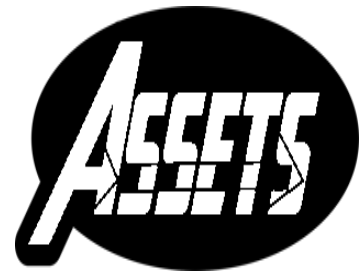

ASSETS:

Jurnal Akuntansi dan Pendidikan Vol. 6 No. 1 Hlmn. 73-84

Madiun, April 2017 p-ISSN: 2302-6251 e-ISSN: 2477-4995

Artikel masuk:

1 Maret 2017

Tanggal diterima:

17 Maret 2017 


\section{ASSEES JURNAL AKUNTANSI DAN PENDIDIKAN

\section{PENDAHULUAN}

Tindakan fraud pada instansi pemerintah merupakan fenomena yang sangat umum. Tindakan ini seolah-olah telah membudaya dan tidak bisa dihilangkan.ACFE, dalam laporannya yang bertajuk Report to The Nation, melakukan pemeringkatan terhadap tindakan fraud yang paling banyak ditemukan pada berbagai sektor. Hasil laporannya pada tahun 2016 mengungkapkan bahwa fraud pada sektor pemerintahan berada pada urutan kedua, setelah sektor perbankan dan pelayanan keuangan. Fenomena global yang mencoreng organisasi yang mengelola uang negara ini disebabkan karena terdapatnya struktur birokrasi yang cukup kompleks, sistem pengendalian yang lemah, dan integritas pegawai yang rendah dalam organisasi tersebut (Sulastri dan Simanjuntak, 2014).

Anggaran yang dikelola yang sejatinya ditujukan untuk mensejahterakan dan melayani masyarakat pada akhirnya berubah fungsi menjadi melayani kelompok tertentu (Setiawan, Irianto, dan Achsin, 2013). Mulai dari proses perencanaan, penganggaran, pembelanjaan, hingga pelaporan, hampir dipastikan tidak luput dari tindakan 'culas' yang dilakukan oleh para aparat pemerintah. Sopanah (2009) menemukan bahwa proses perencanaan yang seharusnya dapat membawa dan mengarahkan pengeluaran negara menjadi lebih efektif dan efisien, pada nyatanya hanya disusun berdasarkan people need assessment, bukan pada government need assessment. Hasil penelitian ini sejalan dengan penelitian oleh Razak, Ludigdo, dan Sukoharsono (2011) yang mengungkapkan bahwa dalam proses penyusunan APBD, masyarakat hanya dijadikan objek partisipasi, karena semua yang tertuang dalam APBD merupakan kepentingan dari pihak eksekutif dan legislatif semata.

Pada pemerintahan Austria, Stalebrink dan Sacco (2007) mengungkapkan bagaimana peluang dan insentif dalam melakukan financial statement fraud dirasionalisasikan sebagai bagian dari jiwa entrepreneurship yang saat itu mengakar kuat di sana dengan menggunakan lensa teori entrepreneurship. Brucker dan Rebele (2010) memberikan contoh sebuah kasus riil tentang fraud dalam sebuah public authority yang dilakukan oleh seorang kepala otoritas petugas akuntansi yang memegang kendali atas unit pemerintahan tersebut, mulai dari penganggaran sampai manajemen pelaporan keuangannya. Huefner (2010) menemukan bahwa terdapatnya ketidakpatuhan terhadap pengendalian internal, kegagalan pengawasan oleh dewan pengawas, serta adanya kolusi antara pihak eksekutif tingkat atas merupakan faktorfaktor yang berkontribusi dalam terjadinya fraud senilai jutaan dolar yang terjadi sepanjang beberapa tahun di sekolah negeri kota New York. Setiawan et al. (2013) menemukan fakta bahwa walaupun secara administrasi pengelolaan keuangan pada instansi pemerintah daerah telah sesuai dengan ketentuan, namun ternyata terdapat penyisihan dana, yang salah satunya bersumber dari selisih antara nilai yang dipertanggungjawabakan dengan realisasi yang disebut sebagai dana taktis.

Kasus-kasus global yang melibatkan bangkrutnya perusahaan-perusahaan besar di dunia seperti Enron, Worldcome, Lehman Brothers, dan berbagai kasus mutakhir lainnya juga merupakan bukti nyata dari akibat tindakan fraud dan berhasil membuat integritas akuntan menjadi sorotan publik (Irianto, 2003). Pada konteks Indonesia pun demikian, tersandungnya nama-nama pejabat publik dalam berbagai kasus korupsi juga merupakan bukti yang menunjukkan bahwasanya anggaran negara telah dijadikan sebagai ajang dalam pemenuhan self interest pihak atau kelompok tertentu saja.

Berbagai upaya untuk menangani kasus-kasus yang merugikan negara tersebut telah dilakukan pemerintah melalui keberadaan lembaga-lembaga penegak hukum seperti KPK, Kejaksaan, dan Kepolisian RI. Upaya-upaya pencegahan pun telah 
dilakukan di antaranya dengan diwajibkannya setiap instansi pemerintah untuk memiliki tim SPI, dibangunnya berbagai sistem elektronik guna menunjang proses transparansi dan akuntabilitas penyelenggaraan kegiatan pemerintah, serta pembayaran tunjangan kinerja yang dilakukan sebagai upaya untuk meningkatkan penghasilan dan membangkitkan gairah bekerja para pegawai pemerintah. Upaya lain yang dilakukan adalah dengan mewajibkan semua aparat publik, khususnya pejabat publik dan pejabat perbendaharaan untuk melaporkan dan mengumumkan jumlah kekayaan yang dimiliki. Hal ini bertujuan agar terpantaunya kewajaran tingkat kekayaan yang dimiliki selama proses menjabat. Bahkan saat ini di Kementerian Perhubungan telah diterapkan Sistem Kendali Kecurangan atau yang dikenal dengan istilah Sikencur. Sikencur ini berfungsi sebagai pendeteksian, pencegahan, pelaporan, dan penanganan tindakan kecurangan pada instansi pemerintah (Kuntandi, 2015).

Berbagai penelitian juga banyak yang dilakukan dengan tema pencegahan dan pendeteksian fraud, di antaranya Pacini dan Hood (2007) tentang peran dari qui tam actions (semacam whistleblowers) dalam pencegahan fraud di sektor pemerintah federal Amerika Serikat. Irianto, Novianti, dan Firmanto (2009) mengungkapkan bahwa sistem organisasi yang baik, integritas, dan lingkungan yang beretika dapat menjadi faktor penentu perilaku etis seseorang, yang berarti jika ketiga aspek tersebut diterapkan maka tindakan yang mengarah kepada fraud dapat dihindari. Penelitian oleh Ghazali et al. (2014) menemukan bahwa pencegahan fraud dapat dilakukan dengan menyediakan sarana telepon bebas pulsa untuk pengaduan fraud, menyediakan kebijakan keamanan komputer dan kode etiknya, pencegahan konflik kepentingan, serta kebijakan investigasi terhadap fraud. Othman, Aris, dan Mardziyah (2015) mengungkapkan bahwa audit operasional, peningkatan komite audit, peningkatan pengendalian internal, dilaksanakannya kebijakan pengaduan fraud, rotasi staf, hotlines fraud, dan akuntan forensik adalah mekanisme yang efektif untuk mencegah dan mendeteksi fraud di sektor publik. Penelitian oleh Sulastri dan Simanjuntak (2014) menunjukkan bahwa keadilan kompensasi dan sistem pengendalian internal berpengaruh terhadap terjadinya fraud, sehingga strategi pencegahan yang dapat ditawarkan adalah memberikan tingkat kompensasi yang cukup untuk pemenuhan taraf hidup yang layak. Penelitian oleh Purnamasari dan Amaliah (2015) menunjukkan bahwa terdapat hubungan positif dan signifikan antara tingkat religius dan spiritualitas seseorang pada pencegahan fraud. Mengacu kepada berbagai hasil penelitian tersebut, dapat disimpulkan bahwa pencegahan fraud secara ringkas sekurang-kurangnya harus menyentuh aspek manusia, aspek sistem, dan lingkungan (Irianto, 2015).

Berbagai upaya pencegahan dan pendeteksian tersebut telah berhasil mengungkap banyaknya kasus fraud yang terjadi. Meskipun demikian, berbagai kasus tersebut hanya merupakan fenomena puncak gunung es karena fraud pada instansi pemerintah merupakan sesuatu yang dilakukan dan diketahui secara berjamaah, yang salah satu penyebabnya adalah kebiasaan dan sistem yang membudaya yang berlangsung dalam instansi tersebut, sehingga bagaimanapun bentuk pengendaliannya, fraud tetap akan dilakukan dengan alasan untuk kepentingan bersama (Setiawan, 2013; Ahabun, 2015; Tandianto 2015). Hal semacam inilah yang pada akhirnya membentuk individu-individu yang awalnya menolak terhadap tindakan fraud, namun dengan alasan atas nama instansi dan kebutuhan bersama, fraud pun menjadi sesuatu yang wajar saja untuk dilakukan. Sebagaimana yang disampaikan Estes (1996), bahwa apa yang berlangsung dalam organisasi akan membentuk dan mempengaruhi prilaku para pegawainya. Watson (2003) pun mengungkapkan hal serupa, bahwa bagaimana sikap seseorang dalam menyikapi fraud dipengaruhi oleh budaya perusahaan tempat mereka bekerja. Dalam sebuah 
artikel bertajuk Business Fraud: Culture Is the Culprit dijelaskan pula bahwa tindakan fraud yang dilakukan oleh seseorang adalah karena mereka makhluk sosial yang secara umum dipengaruhi oleh budaya dan lingkungan dimana mereka berada (Raftery dan Holder, 2014). Beranjak dari kondisi inilah, maka penelitian ini dilakukan dengan tujuan untuk mengungkap budaya yang merupakan pemicu dilakukannya fraud dalam realisasi keuangan negara. Pengungkapan hal ini akan memberikan kontribusi agar pencegahan fraud dapat lebih tepat sasaran dan dilakukan dengan sedini mungkin.

\section{METODE PENELITIAN}

Penelitian ini merupakan sebuah upaya untuk mengungkap budaya pemicu terjadinya fraud. Oleh karena itu, pendekatan interpretif dengan metode etnografi ala Spradley dianggap sebagai pijakan yang paling tepat untuk mengungkap budaya pemicu tersebut. Keberhasilan dari penelitian jenis ini sangat tergantung pada kemampuan peneliti dalam mengintegrasikan ketiga hal yang diungkapkan oleh Spradley (1997: 10), yaitu pengetahuan budaya, perilaku, dan artefak atau bendabenda budaya yang ditinggalkan. Strategi penulisan etnografi menurut Spradley ini terdiri atas lima prinsip, yakni menyarankan peneliti untuk memilih teknik pengumpulan data, mengenali langkah-langkah penelitian, menjalankan setiap langkah secara berurutan, melakukan praktik penelitian secara orisinil, dan memberikan pemecahan masalah sebagai bentuk tanggung jawab sosial. Kelima prinsip tersebut dirangkum dalam Alur Penelitian Maju Bertahap (development research process), yang selanjutnya dirinci ke dalam dua belas tahapan, yaitu menetapkan informan, mewawancarai informan, membuat catatan etnografis, mengajukan pertanyaan deskriptif, melakukan analisis wawancara etnografis, melakukan analisis domain, mengajukan pertanyaan struktural, melakukan analisis taksonomi, mengajukan pertanyaan kontras, melakukan analisis komponen, menemukan tematema budaya, dan menulis etnografi.

Penelitian dilakukan pada salah satu instansi pemerintah di daerah, pada provinsi ABC. Informan kunci ditetapkan berdasarkan kriteria yang dikemukan oleh Spradley (1997:61) yaitu mereka yang memahami konteks objek penelitian yang dapat dilihat dari lamanya informan tersebut berada pada budaya tersebut, memiliki keterlibatan dalam keseharian komunitas yang diteliti, menggunakan bahasa asli sendiri dalam menyampaikan informasi, memiliki waktu yang cukup untuk mengikuti serangkaian penelitian etnografi, dan bahwa informan bukanlah seorang analis, melainkan seseorang yang memahami dan mengerti teks dan konteks yang diteliti. Berdasarkan kriteria tersebut, maka pihak yang dijadikan informan adalah mereka yang terlibat secara langsung dengan pengelolaan keuangan negara dan bersentuhan dengan fraud, baik sebagai pelaku inti maupun sebagai saksi kunci, yaitu: (1) Pak Indra, Pejabat Pembuat Komitmen; (2) Mas Fajar, Bendahara Pengeluaran; (3) Mas Ogi, Bendahara Pengeluaran Pembantu; (4) Mas Adi, Bendahara Pengeluaran Pembantu; (5) Mbak Ika, anggota Tim SPI. Karena isu yang diangkat pada penelitian ini cukup sensitif, maka demi kenyamanan informan, identitas mereka dirahasiakan sehingga nama-nama mereka tersebut merupakan nama samaran.

Teknik pengumpulan data dilakukan dengan tiga cara, yaitu wawancara mendalam, observasi partisipasi, dan dokumentasi. Ketiga teknik ini dilakukan secara bersamaan, artinya ketika peneliti melakukan observasi peneliti sekaligus juga akan melakukan wawancara dan dokumentasi, dan begitu seterusnya hingga informasi yang diperoleh dirasa cukup. Sebelum terjun ke lapangan, peneliti akan terlebih dahulu menyiapkan beberapa pertanyaan mendasar yang akan diajukan pada saat 
proses wawancara, karena kesiapan materi pertanyaan ini merupakan salah satu faktor penentu keberhasilan penggalian informasi melalui proses wawancara. Proses wawancara tidak dilakukan dalam konteks yang formal, melainkan dalam suasana yang santai. Dalam melakukan wawancara, peneliti tidak menyampaikan pertanyaan seputar faud secara to the point, melainkan melalui pendekatan-pendekatan yang sedemikian rupa agar informan tidak merasa tersinggung atau terhakimi dengan pertanyaan yang diajukan. Proses observasi dilakukan pada berbagai dokumen sumber, serta aktifitas dan interaksi informan, baik dalam hal pengelolaan keuangan negara maupun dalam hal aktifitas kesehariannya.

Teknik analisis dilakukan melalui empat tahap sesuai dengan alur penelitian maju bertahap ala Spradley, yaitu (1) analisis domain (2) analisis taksonomi, (3) analisis komponensial, dan (4) analisis tema budaya. Proses analisis data dilakukan secara simultan dengan proses pengumpulan data, hal ini dikarenakan teknik analisis dengan alur penelitian maju bertahap ala Spradley memerlukan konfirmasi berulang untuk dapat maju pada tahap berikutnya.

\section{HASIL PENELITIAN DAN PEMBAHASAN}

Berdasarkan tahap analisis yang telah dilakukan, diketahui bahwa budaya yang memicu terjadinya fraud pada instansi yang diteliti adalah budaya cari untung. Budaya cari untung ini terlihat dari kebiasaan para pegawainya dalam "memanfaatkan" kebutuhan instansi, kebiasaan menyalahgunakan kewenangan yang dimiliki, dan kebiasaan menyiasati beberapa peraturan tentang keuangan negara untuk peningkatan pemasukan pribadi maupun kelompoknya.

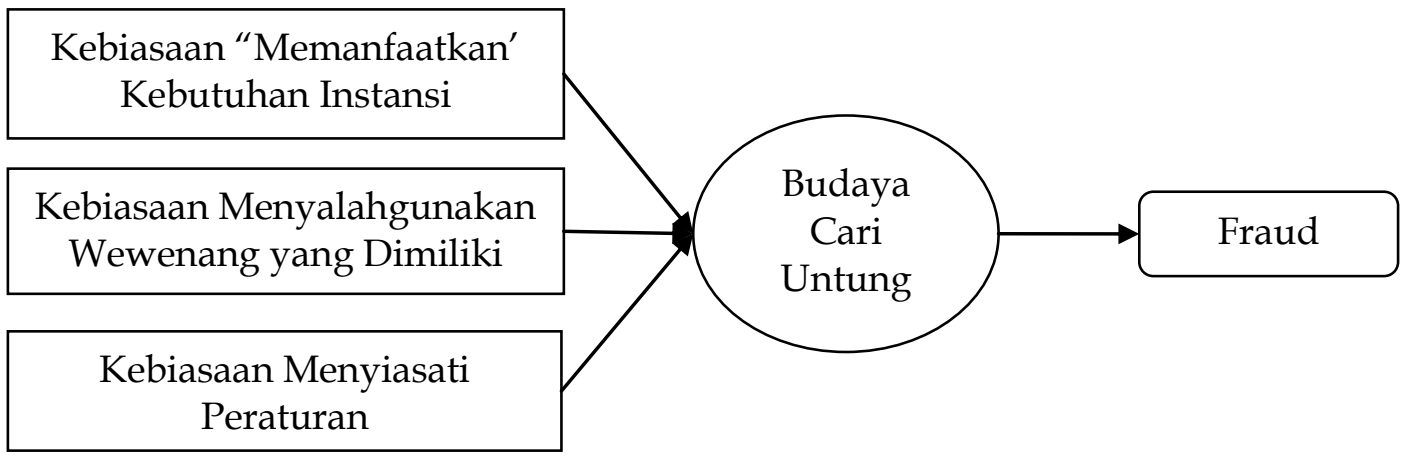

Gambar 1. Hasil Temuan Penelitian

\section{Kebiasaan "Memanfaatkan" Kebutuhan Instansi}

Sebagaimana instansi pada umumnya, instansi ini memiliki berbagai kebutuhan, baik yang benar-benar dibutuhkan maupun yang sebenarnya dapat dihindari, yang "terpaksa" dipenuhi dengan mekanisme fraud. Atas berbagai kebutuhan tersebut, terbuka celah untuk melakukan fraud yang pada akhirnya bertujuan untuk kepentingan pribadi. Seperti yang dituturkan oleh Mas Adi berikut:

"Pasti Mba, untuk THR misalnya. Awalnya memang karena niatan untuk kesejahteraan staf seksi. Tapi kemudian terbesit juga untuk mencarikan yang agak banyak supaya Saya sebagai bagian dari staf seksi juga bisa dapat banyak. Ini kan sudah merujuk kepada kepentingan pribadi yang bernanung di bawah faktor tekanan tadi."

Apa yang dialami oleh Mas Adi tersebut, terjadi pula pada para bendahara yang lain. Adanya penyisihan anggaran yang mereka lakukan untuk berbagai kebutuhan 


\section{ASSEIS JURNAL AKUNTANSI DAN PENDIDIKAN

seperti THR, pajak, sumbangan sosial, dan pengembalian temuan, pada akhirnya, disadari atau tidak, bertujuan untuk kepentingan pribadi mereka juga. Karena jika sampai pada akhir tahun, anggaran penyisihan atau yang disebut dengan dana saving tersebut masih bersisa, maka akan dilakukan pembagian sesuai dengan porsinya. Kondisi semacam ini serupa dengan apa yang ditemukan oleh Setiawan et al. (2013) bahwa salah satu tujuan dari keberadaan dana saving adalah sebagai dana taktis yang akan dibagi untuk kesejahteraan pegawai. Pembagian ini tentu tidak dilakukan secara merata, bergantung pada kontribusi masing-masing pihak.

Kebiasaan menyalahgunakan kebutuhan instansi dengan kondisi semacam itu terjadi pula dalam hal membelanjakan atau menyediakan barang kebutuhan. Peluang dari dibutuhkannya selisih nilai untuk berbagai kebutuhan dana taktis tersebut, digunakan oleh kalangan oknum tertentu untuk mendapatkan keuntungan secara tersendiri terlebih dahulu. Artinya, terdapat dua kali selisih atas belanja tersebut, selisih yang pertama adalah antara nilai yang benar-benar dibelanjakan dan nilai yang dilaporkan ke instansi, yang mana selisihnya masuk kantong pribadi. Selisih yang kedua adalah nilai yang dilaporkan ke instansi dengan nilai yang diSPJkan, dan selisihnya disimpan untuk kebutuhan instansi.

Bentuk lain dari kebiasaan memanfaatkan kebutuhan instansi ini terjadi pula ketika Mas Fajar harus melakukan tindakan fraud untuk membayarkan honorarium narasumber pusat yang karena secara ketentuan tidak diperbolehkan untuk dibayarkan. Bentuk fraud yang dilakukannya adalah dengan meninggikan jumlah jam narasumber lain yang boleh dibayarkan honornya, sehingga apa yang ditandatangan oleh si narasumber tersebut tidak sesuai dengan apa yang diterimanya. Hal ini tentu saja dilakukan dengan seijin dari si narasumber yang dipinjam namanya tersebut, dan karena alasan yang diutarakan cukup logis dan manusiawi, Mas Fajar pun tidak sungkan untuk mengungkapkan kebenarannya, sehingga tidak ada dusta di antara mereka. Kondisi semacam ini kemudian membuka peluang bagi para pimpinan di instansi ini. Dengan alasan juga telah memberikan arahan dan binaan dalam kegiatan yang diselenggarakan, maka mereka pun merasa layak untuk memperoleh imbalan atas jasa nya tersebut, meskipun proses pengarahan dan pembinaan tersebut dilaksanakan di kantornya sendiri dan terhadap para bawahan langsung nya sendiri. Kondisi inilah yang menyebabkan jika seharusnya "nebeng" SPJ narasumber lain itu hanya dilakukan untuk narasumber dari pusat, maka tindakan ini pun dilakukan juga untuk pemenuhan imbalan para unsur pimpinan tersebut.

\section{Kebiasaan Menyalahgunakan Kewenangan yang Dimiliki}

Dalam struktur kepegawaian yang berbasis kinerja saat ini, pada masing-masing pegawai telah melekat jabatan nya sendiri. Dengan jabatan nya tersebut, setiap pegawai telah memiliki kewenangan atas apa yang harus dilakukannya, sehingga konteks kewenangan tidak hanya berlaku bagi para pejabat, tetapi juga bagi para pegawai secara keseluruhan. Kewenangan seseorang tentu harus diiringi dengan tanggung jawab pekerjaan yang harus dilaksanakan. Namun apa yang terjadi di instansi ini, kewenangan tersebut cenderung disalahgunakan, untuk pemenuhan kepentingan pribadi.

Salah satu bentuk penyalahgunaan kewenangan yang sering dilakukan di instansi ini adalah kewenangan yang dimiliki oleh pimpinan dalam pendelegasian tugas untuk melakukan perjalanan dinas. Dalam rangka menghadiri undangan kegiatan yang diselenggarakan oleh direktorat, pimpinan memiliki wewenang untuk menugaskan siapa saja agar mengikuti kegiatan tersebut dengan mengacu pada perihal pelaksanaan kegiatan, termasuk dirinya sendiri. Karena sifatnya menghadiri 
undangan, maka kegiatan seperti ini biasanya diselenggarakan dengan paket fullboard yang artinya sebagaimana yang diatur dalam PMK 65, besaran uang saku yang diperoleh nilainya jauh relatif kecil dibandingkan apabila yang menghadiri undangan tersebut berangkat dengan biaya instansi sendiri. Oleh karena itu, agar pejabat yang diundang dapat terhindar dari uang saku yang kecil ini, maka biasanya pejabat tersebut akan menugaskan stafnya untuk mengikuti kegiatan tersebut dengan biaya yang ditanggung oleh panitia penyelenggara, sedangkan pejabat yang bersangkutan berangkat sendiri dengan anggaran dari kantor, sehingga dapat terbebas dari paket fullboard dan dapat memperoleh uang harian yang nilainya relatif labih besar. Tidak ada ketentuan yang dilanggar memang pada kondisi ini, namun merupakan bentuk penyelahgunaan kewenangan yang berakibat pada pemborosan anggaran negara untuk kepentingan pribadi. Seperti yang diutarakan oleh salah satu bendahara pengeluaran pembantu, penyiasatan jenis ini jauh lebih manusiawi.

Dalam hal belanja pengadaan, penyalahgunaan kewenangan kerap digunakan dalam proses pengadaan barang jasa yang sifatnya penunjukan langsung. Karena adanya kesempatan ini, pejabat terkait biasanya akan menunjuk rekanan "bawaan" nya sendiri. Hal semacam ini cukup kerap terjadi, bahkan masing-masing bagian di instansi ini seolah telah memiliki bawaan nya masing-masing. Selama barang atau jasa yang disediakan tersebut memang benar-benar sesuai dengan apa yang dibutuhkan dan dapat dipertanggungjawabkan, maka budaya semacam ini tentu tidak masalah untuk diberlangsungkan. Hanya saja kadang, karena orientasi nya lebih kepada keuntungan yang diperoleh, maka barang dan jasa yang disediakan banyak yang tidak sesuai dengan apa yang diharapkan. Alih-alih menuntut rekanan untuk mengganti barang tersebut, yang ada malah mengganti kontrak yang ada untuk menyesuaikan dengan spek barang yang datang. Semua pihak yang berkaitan dengan proses pengadaan semacam ini tidak ada yang dapat bersikap tegas, karena masing-masing mereka juga mendapatkan keuntungan dari kontrak dengan rekanan tersebut.

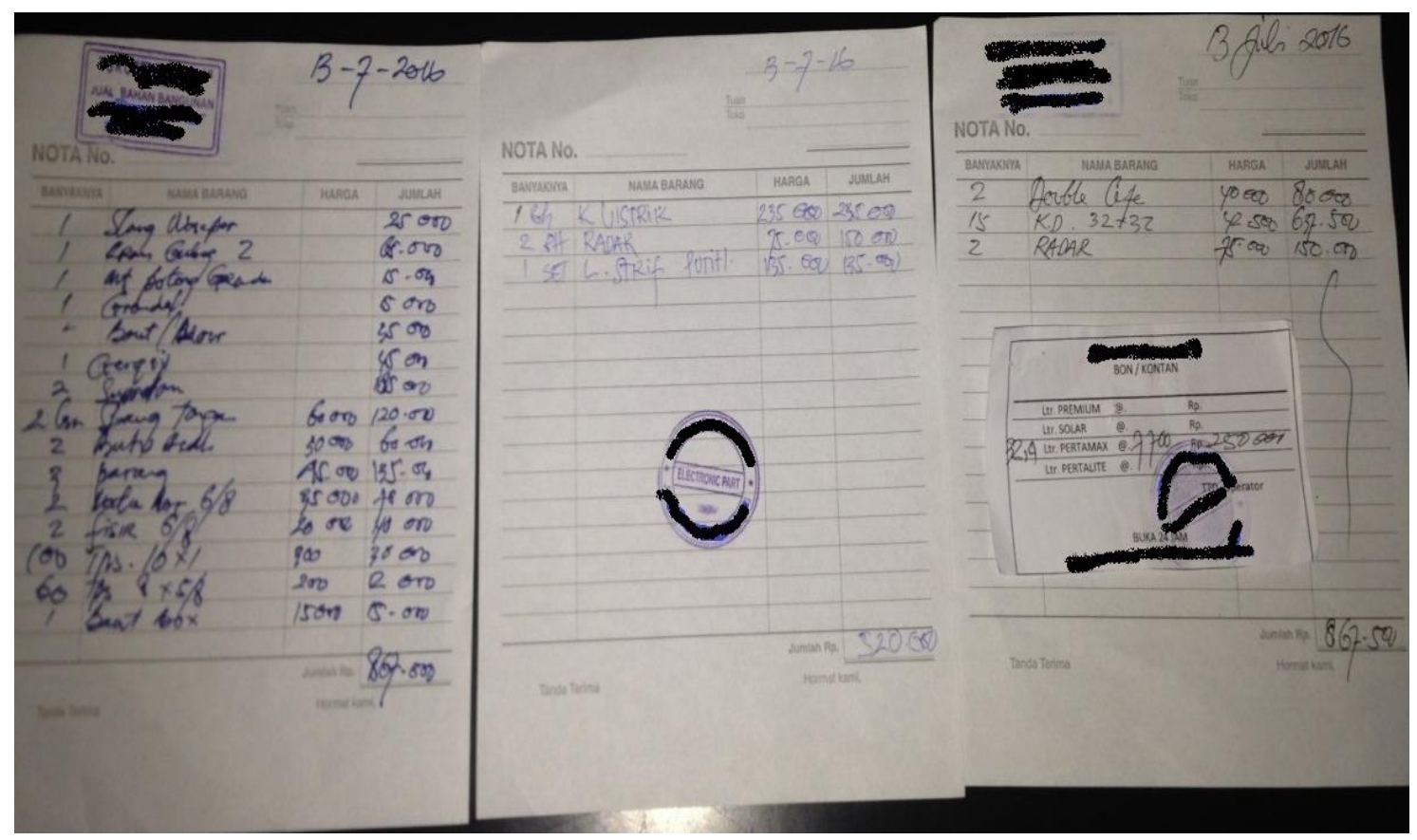

Gambar 2. Contoh Bukti Pengeluaran dengan Tulisan Tangan yang Sama

Selain unsur pimpinan, pegawai pun juga tidak mau tertinggal dari penyelahgunaan kewenangan ini. Salah satu bentuk nya adalah apa yang dilakukan 
oleh Pak Sugeng dengan jabatan yang dimilikinya sebagai kepala urusan rumah tangga. Dengan kewenangan yang dimiliki atas jabatan tersebut, Pak Sugeng cukup sering melakukan belanja untuk berbagai keperluan rumah tangga seperti urusan pemeliharaan, keamanan, kebersihan, dan jamuan tamu. Belanja untuk berbagai keperluan tersebut biasa nya dikeluarkan dengan uang pribadi nya terlebih dahulu, setelah bukti pengeluaran terkumpul banyak barulah dia mengajukan klaim kepada bendahara. Dari berbagai kumpulan bukti pengeluaran ini lah ditemukan bukti yang mengandung kecurangan untuk kepentingan pribadi nya Pak Sugeng. Beberapa bentuk kecurangan tersebut terlihat dari ditemukannya bukti yang memiliki tulisan tangan yang sama, padahal berasal dari toko yang berbeda. Jika diamati dengan lebih seksama, jelas terlihat bahwa tulisan itu adalah tulisan tangan nya Pak Sugeng sendiri, namun berusaha dibedakan dengan menggunakan pulpen yang berbeda warna, pengunaan huruf besar dan huruf kecil, serta tulisan yang dimiringkan atau tegak lurus seperti yang terlihat pada Gambar 2.

\section{Kebiasaan Menyisati Peraturan}

Peraturan lazimnya dibuat untuk dipatuhi, namun karena peraturan merupakan produk buatan manusia, tentu tidak luput dari berbagai kekurangan. Pada berbagai kondisi, terdapat beberapa peraturan yang cukup sulit untuk diimplementasikan, sementara dalam penyelenggaraan anggaran negara, para aparatur sipil tidak diperkenankan untuk melanggar peraturan tersebut. Kondisi inilah yang lantas menyebabkan munculnya tindakan menyiasati peraturan. Selain karena peraturan tersebut cukup sulit untuk dilaksanakan, penyiasatan terjadi pula karena peluang yang diberikan oleh peraturan.

Salah satu peraturan yang benar-benar memberikan celah untuk disalahgunakan oleh semua pegawai di instansi ini adalah peraturan yang mengatur tentang tarif $30 \%$ yang diperbolehkan untuk penginapan dalam perjalanan dinas yang dijelaskan secara lebih detail dalam PMK 113 tahun 2012 berikut:

"Dalam hal pelaksana SPD tidak menggunakan biaya penginapan, maka pelaksana SPD diberikan biaya penginapan sebesar 30\% dari tarif hotel di kota tempat tujuan sebagaimanan diatur dalam Peraturan Menteri Keuangan."

Atas peraturan tersebut, sering terjadi perjalanan dinas yang SPJ nya dilaksanakan untuk waktu tiga hari, namun hanya dilakukan selama dua hari. Kondisi ini dapat terjadi karena pada malam kedua mereka hanya menggunakan tarif $30 \%$ tersebut sehingga tidak ada kewajiban untuk tetap bermalam agar dapat memperoleh bukti fisik penginapan. Perjalanan dinas yang seharusnya dilakukan untuk tiga hari, dipadatkan menjadi dua hari demi mengejar keuntungan. Tidak hanya keuntungan materi, namun juga keuntungan dalam bentuk lain berupa jatah "bolos" satu hari. Seperti yang diutarakan oleh Mas Fajar, sebagai pegawai yang cukup sering melakukan penyiasatan ini:

"Kalau bisa hemat dua hari kan lumayan Mba, sisa seharinya bisa istirahat di rumah trus bisa bawa pulang oleh-oleh dari 30\% hotel."

Peluang dari tarif $30 \%$ ini dimanfaatkan pula dengan cara nebeng satu kamar dengan rekan perjalanan dinasnya, namun klaim atas 30\% tetap diajukan, sehingga apabila dalam perjalanan dinas yang dilakukan untuk tiga hari namun dihemat menjadi dua hari, maka akan ada kelebihan yang bisa diperoleh sebesar 30\% dikali 
tiga. Satu kali sebagai penggantian nebeng di kamar teman dan dua kali berupa penggantian penginapan yang tidak dilakukan pada malam kedua.

Ketentuan tentang 30\% ini memang membuka peluang yang cukup besar untuk dimanfaatkan, karena tidak ada persyaratan apapun yang harus dipenuhi agar mendapatkan penggantian 30\% tersebut. Artinya sebenarnya apa yang dilakukan oleh para pegawai di instansi ini cukup logis, karena mereka hanya memanfaatan "fasilitas" yang diberikan oleh peraturan dan secara administrasi pengSPJan tidak ada ketentuan yang mereka langgar. Namun yang membuat miris adalah peluang ini kerap disalahgunakan secara berlebihan oleh oknum tertentu. Kerap terjadi penyimpangan terhadap surat tugas, hanya karena longgarnya ketentuan terhadap bukti fisik yang melekat pada SPJ perjalanan dinas ini. Seperti misalnya pegawai yang ditugaskan berangkat adalah tiga orang, tapi kenyataannya yang berangkat hanya satu orang dengan membawa SPD untuk tiga orang, dan penginapan untuk dua orang yang tidak berangkat akan diklaim dengan ketentuan 30\%. Apabila kebiasaan ini berlanjut terus, dapat dibayangkan berapa banyak uang negara yang terbuang percuma karena peluang yang ada ini.

Kebiasaan menyiasati peraturan ini terjadi pula pada ketentuan yang mengatur tentang tiket perjalanan yang memperbolehkan tiket kepulangan diganti sebesar tiket keberangkatan seperti yang diatur dalam PMK 113 tahun 2012:

“Biaya transport kepulangan pelaksana SPD dalam rangka mengikuti rapat, seminar, dan sejenisnya dapat dibayarkan sebesar biaya transport kedatangan tanpa menyertakan bukti pengeluaran transport kepulangan."

Peraturan tersebut memberikan peluang, khususnya dalam kegiatan yang diselenggarakan dengan paket fullboard sehingga hampir semua pelaksana perjalanan dinas akan menyerahkan tiket berangkat dengan harga yang paling tinggi dan selanjutnya membeli tiket pulang dengan harga yang paling murah. Bisa jadi peluang semacam ini sengaja diberikan oleh Kementerian Keuangan selaku pembuat aturan, sebagai ganti atas kecilnya uang saku yang mereka peroleh dari paket fullboard tersebut.

Namun dengan sedikit penyiasatan yang lebih "cerdas", peluang yang diciptakan dari peraturan tersebut akan dapat memberikan keuntungan yang cukup besar. Untuk mempermudah proses pemahaman, penjelasan akan peneliti uraikan dalam sebuah ilustrasi. Pak Indra mendapatkan undangan untuk menghadiri kegiatan yang diselenggarakan oleh di Palu selama tiga hari. Kegiatan tersebut dilaksanakan mulai dari tanggal 1 hingga tanggal 3. Sementara itu, Pak Indra juga memiliki tugas dari instansinya sendiri untuk melakukan perjalanan dinas ke kota Kendari yang mana tanggal berangkatnya dapat dikondisikan sendiri. Dalam rangka penghematan anggaran (seperti alasan yang diungkapkan pertama kali), maka perjalanan menuju Kendari pun akan dimulai langsung dari Palu pada tanggal 3 tersebut, tanpa harus kembali dahulu ke kota asal. Artinya, apabila biaya dari Palu menuju Kendari ini ditanggung oleh pihak pengundang, maka instansi tidak akan lagi membayarkan biaya keberangkatan menuju Kendari, dan begitu pula sebaliknya. Salah satu pihak hanya akan membayarkan satu kali rute perjalanan saja.

Namun pada kenyataanya, selain dalam rangka efisiensi, perjalanan dinas sambung ini juga berpeluang untuk dilakukannya fraud. Dengan tidak diserahkannya tiket pulang tersebut, maka pihak penyelenggara tidak dapat mengetahui bahwa Pak Indra tidak langsung pulang ke kota instansi, dan mereka tetap membayarakan tiket pulang sebesar tiket berangkat dengan asumsi pelaksana SPD kembali ke kota asal 


\section{ASSEIS JURNAL AKUNTANSI DAN PENDIDIKAN

instansi. Selanjutnya, tiket Palu-Kendari yang sebenarnya telah dibayarkan ini, diklaim lagi ke instansi dengan alasan tidak diganti oleh panitia kegiatan sebelumnya, sehingga dari sini Pak Indra akan mendapatkan double penggantian untuk satu kali rute perjalanan.

Bentuk lain dari penyiasatan dilakukan pula pada peraturan yang mengatur tentang pembayaran uang saku rapat dalam kantor. Atas ketentuan semacam ini, maka penyiasatan yang dilakukan agar rapat dalam kantor pada jam kerja tetap mendapatkan uang saku adalah dengan mengkondisikan seolah-olah rapat tersebut dilakukan di luar jam kantor. Hal ini tentu saja harus didukung dengan surat tugas dari pimpinan serta keterlibatan pihak lain yang direkayasa dalam daftar hadir rapat sebagai bagian dari perwakilan masyarakat atau Eselon II lainnya. Pada PMK 65 tahun 2015, dijelaskan bahwa:

“Uang saku rapat dalam kantor hanya dapat dibayarkan apabila: rapat tersebut dihadiri oleh masyarakat atau perwakilan dari eselon II lainnya; dilakukan minimal tiga jam di luar jam kantor; dan tidak dianggap sebagai lembur, sehingga bebas dari uang lembur dan uang makan lembur."

Ketentuan lain pada PMK 65 yang juga pernah disiasati adalah terkait pembayaran honorarium narasumber yang diuraikan sebagai berikut:

"Honorarium narasumber/pembahas dapat diberikan dengan ketentuan: a) berasal dari luar lingkup unit eselon 1 penyelenggara; dan atau b) berasal dari lingkup unit eselon I penyelenggara sepanjang peserta yang menjadi sasaran utama kegiatan berasal dari luar lingkup unit eselon I penyelenggara/masyarakat"

Ketentuan tersebut menyatakan bahwa pembayaran atas honorarium yang berasal dari satu eselon yang sama tidak diperbolehkan. Ketentuan ini memang terlihat wajar dan mudah untuk diimplementasikan karena sudah sewajarnya seorang pimpinan yang berada di tingkat pusat memberikan pembinaan kepada para pegawainya yang berada di daerah. Namun dalam implementasinya, hal ini cukup sulit untuk direalisasikan. Seperti yang dituturkan Mas Fajar berikut:

"Masa iya sih orang jauh-jauh dari Jakarta ga dikasih honor apa-apa, pejabat pula yang datang. Iya kalau dia paham peraturan tersebut, kalau ga siapa yang mau jelasin?"(sambil tersenyum)

Terlebih lagi karena ketentuan semacam ini baru diberlakukan dalam dua tahun terakhir, sehingga masih diperlukan semacam penyesuaian baik oleh si narasumber yang bersangkutan maupun bagi si instansi pengundang. Mengundang pejabat dari pusat untuk memberikan pembinaan pada kegiatan yang diselenggarakan di daerah, tanpa diberikan honor apapun atas jasa nya tersebut, dianggap cukup "mencoreng" nama baik instansi khususnya para unsur pimpinan. Pada akhirnya, demi menjaga nama baik di kalangan para pejabat pusat, pimpinan pun memilih untuk tidak mau tahu dengan ketentuan semacam tersebut. Demi menjaga "wibawa", langkah apapun sah-sah saja untuk dilakukan. Akhirnya, Mas Fajar pun melakukan penyiasatan sebagaimana yang diutarakannya berikut:

"Nebeng SPJ narasumber lain! SPJ narasumber dari eselon lain ditambah jamnya tapi untuk bayar narasumber dari pusat." 
Cara seperti ini tidak melanggar ketentuan terhadap pembayaran honorarium ini, si pejabat pusat tetap dapat menerima "hak" nya, nama baik instansi tetap terjaga, para pimpinan pun masih bisa untuk bernafas lega. Sebuah win win solution yang mengakibatkan pemborosan uang negara.

Bentuk penyiasatan lain yang pernah dilakukan terhadap ketentuan ini adalah dengan menambahkan satu dua orang peserta yang berasal dari masyarakat atau unit eselon I lainnya. Hal ini didasarkan atas penjelasan dalam ketentuan tersebut, bahwa salah satu syarat agar pembayaran honorarium narasumber dapat dibayarkan adalah apabila sasaran utama dari kegiatan tersebut berasal dari masyarakat atau eselon I lainnya. Namun semenjak ada arahan dari irjen bahwa sasaran peserta yang berasal dari luar Eselon I yang dimaksud haruslah berupa sasaran utama, maka nebeng honor pada narasumber lain pun menjadi alternatif penyiasatan selanjutnya.

\section{SIMPULAN}

Salah satu budaya yang memicu terjadinya fraud dalam realisasi keuangan negara adalah budaya cari untung. Budaya ini terlihat dari: a) kebiasaan "memanfaatkan" kebutuhan instansi, b) kebiasaan menyalahgunakan wewenang yang dimiliki, c) kebiasaan menyiasati peraturan keuangan negara, yang dilakukan untuk meningkatkan keuntungan pribadi. Peraturan yang kerap disiasati yaitu PMK 113 yang mengatur tentang tarif $30 \%$ yang diperbolehkan untuk pelaksana SPD yang tidak menggunakan jasa penginapan/hotel, ketentuan tentang pembayaran tiket kepulangan sebesar tiket keberangkatan, dan PMK 65 tentang pembayaran honor narasumber dan pembayaran uang saku rapat. Hasil penelitian ini memberikan informasi berupa bentuk penyiasatan yang dilakukan, sehingga dapat menjadi dasar sebagai pertimbangan untuk perubahan kebijakan maupun peraturan yang disiasati tersebut, agar dapat meminimalisir terjadinya fraud dalam instansi pemerintah. Penelitian ini memiliki keterbatasan, yaitu bentuk penyiasatan yang dikaji hanya berfokus pada fraud pada realisasi belanja barang dan jasa. Hal ini disebabkan karena keterbatasan ketersediaan informan sehingga fraud pada penyiasatan belanja lainya seperti belanja modal dan belanja pegawai tidak terungkap.

\section{DAFTAR PUSTAKA}

Ahabun, H. (2015). Makna Fraud bagi Pengelola Keuangan Daerah: Kenikmatan yang Dilematis (Sebuah Studi Fenomenologi). Universitas Brawijaya.

Association of Certified Faud Examiners. (2014). Report To the Nations on Occupational Fraud and Abuse: 2014 Global Fraud Study. Diakses pada 29 Februari 2016, dari http://www.acfe.com.

Brucker, W. G., dan Rebele, J. E. (2010). Fraud at A Public Authority. Journal of Accounting Education, 28(1), 26-37.

Estes, R. (1996). Tyranny of the Bottom Line: Why Corporations Make Good People Do Bad Things. USA: Berret-Koehler Publisher.

Ghazali, M.Z., Rahim, M.S., Ali. A., dan Abidin, S. (2014). A Preliminary Study on Fraud Prevention and Detection at the State and Local Government Entities in Malaysia.Procedia-Social and Behavioral Sciences, 164, 437-444.

Huefner, R.J. (2010). Local Government Fraud: The Roslyn School District Case. Management Research Review, 33, 198-209.

Irianto, G. (2003). Skandal Korporasi dan Akuntan. Lintasan Ekonomi, XX(2), 104-114.

Irianto, G., Novianti, N., Rosalina, K., dan Firmanto, Y. (2009). Integrity, Unethical Behavior, and Tendency of Fraud. Ekuitas: Jurnal Ekonomi Dan Keuangan, 16(2), 144-163. 
Irianto, G. (2015). Spirit Profetik, Akuntan, dan Pencegahan Fraud. Pidato Pengukuhan Jabatan Guru Besar dalam Bidang Ilmu Akuntansi Sektor Publik pada Fakultas Ekonomi dan Bisnis. Universitas Brawijaya. Malang, 10 Desember 2015.

Kuntandi, C. (2015). Sikencur, Menata Birokrasi Bebas Korupsi. Jakarta: Elex Media Komputindo.

Othman, R., Aris, N. A., Mardziyah, A., Zainan, N., dan Amin, N.M. (2015). Fraud Detection and Prevention Methods in the Malaysian Public Sector: Accountants' and Internal Auditors' Perceptions. Procedia Economics and Finance, 28(April), 59-67.

Pacini, C. dan Hood, M.B. (2007). The Role of Qui Tam Actions Under the False Claims Act in Preventing and Deterring Fraud Against Government. Institutional Repository. Diakses pada 20 Februari 2016, dari http:/ / repository.law.miami.edu/umblr.

Peraturan Menteri Keuangan Republik Indonesia Nomor 113/PMK.05/2012 tentang Perjalanan Dinas dalam Negeri bagi Pejabat Negara, Pegawai Negeri, dan Pegawai Tidak Tetap.

Peraturan Menteri Keuangan Republik Indonesia Nomor 65/PMK.02/2015 tentang Standar Biaya Masukan Tahun Anggaran 2016.

Purnamasari, P. dan Amaliah, I. (2015). Fraud Prevention: Relevance to Religiosity and Spirituality in the Workplace. Procedia - Social and Behavioral Sciences, 211, 827835.

Raftery, H. dan Holder, F.L. (2014). Business Fraud: Culture Is the Culprit. Diakses pada 13 Februari 2016, dari http://ftijournal.com/article/business-fraudculture-is-the-culprit.

Razak, A., Ludigdo, U., dan Sukoharsono, E. G. (2011). Perilaku Kuasa Eksekutif dan Legislatif dalam Proses Penyusunan Anggaran Pemerintah Daerah: Perspektif Interaksionisme Simbolik. Jurnal Akuntansi Multiparadigma, 2(3), 492-509.

Setiawan, A.R., Irianto, G., Achsin, M. (2013). System-Driven (Un)Fraud: Tafsir Aparatur terhadap "Sisi Gelap" Pengelolaan Keuangan Daerah. Jurnal Akuntansi Multiparadigma, 4, 85-100.

Sopanah. (2009). Studi Fenomenologis : Menguak Partisipasi Masyarakat dalam Proses Penyusunan APBD. Simposium Nasional Akuntansi 12 Palembang, (1354), 1-27.

Spradley, J.P. (1997). Metode Etnografi. Yogyakarta: Tiara Wacana Yogya.

Stalebrink, O.J. dan Sacco, J.F. (2007). Rationalization of Financial Statement Fraud in Government: An Austrian Perspective. Critical Perspectives on Accounting, 18, 489-507.

Sulastri dan Simanjuntak, B.H. (2014). Fraud pada Sektor Pemerintah Berdasarkan Faktor Keadilan Kompensasi, Sistem Pengendalian Internal, dan Etika Organisasi Pemerintah (Studi Empiris Dinas Pemerintah Provinsi DKI Jakarta). E-Journal Magister Akuntansi Trisakti, 1(2), 199-227.

Tandianto, R.A. (2015). Fraud dan Pencegahannya di Sektor Publik Catatan Bendahara Pengeluaran. Universitas Brawijaya.

Watson, D.M. (2003). Cultural Dynamics of Corporate Fraud. Cross Cultural Management, 10(1), 40-45 